\title{
Investigation of Wettability Using Contact Angle Measurements and Geometric Discrepancy Analysis of Heat-Treated Pure Titanium Grade 2
}

\author{
Gustavo dos Santos De Lucca * (1), Anderson Daleffe ${ }^{a}\left(\mathbb{1}\right.$, Gustavo Sebastião Scheffer ${ }^{a}$, \\ Marcio Afonso de Souza ${ }^{a}$, Clauber Roberto Marques ${ }^{a}$,Jovani Castelan ${ }^{a}(1)$, Lirio Schaeffer $^{b}$ () \\ ${ }^{a}$ Centro Universitário SATC (UniSATC), Criciúma, SC, Brasil. \\ ${ }^{b}$ Universidade Federal do Rio Grande do Sul (UFRGS), Programa de Pós-Graduação em Engenharia \\ de Minas, Metalúrgica e Materiais (PPG3M), Laboratório de Transformação Mecânica (LdTM), Porto \\ Alegre, RS, Brasil.
}

Received: February 27, 2021; Revised: April 17, 2021; Accepted: May 30, 2021

\begin{abstract}
This study aimed to analyze the wettability characteristics applied to the surface of heat-treated pure titanium grade 2. Titanium is widely used for applications in implants produced by incremental sheet forming (ISF), where the 3D model resulting from tomography was used to produce the part. Since the ISF process creates residual stresses in the sheet, heat treatments were applied to relieve them. Also analyzed were roughness, researching what the literature recommends to enable surface wettability. Tests were conducted to assess geometric discrepancy using 3D scanning. The results obtained prove the efficacy of the experiment in assessing wettability as a characteristic of bioactivity, which is necessary for applications involving the human body. In addition, geometric discrepancy analysis enables the prosthesis to be used with the best esthetic and functional comfort possible.
\end{abstract}

Keywords: Incremental Sheet Forming, Wettability, Titaium Cp grade 2, 3D Scanning.

\section{Introduction}

Titanium alloys have been widely used in biomedical devices due to their excellent mechanical, physical and biological characteristics. Titanium is largely used to replace bone tissues and joints, in dental implants, oral and maxillofacial restorations, cardiovascular devices (stents), external orthoses (temporary prostheses) and surgical instrumentation ${ }^{1,2}$. These applications are due to their excellent mechanical properties, such as low modulus of elasticity (in relation to steel, but an average of 4 to 5 times superior to human bone), resistance to corrosion (superior to stainless steel and cobalt alloys) and biocompatibility characteristics ${ }^{3}$. The metallic materials used for biomedical purposes include stainless steel, Co-Cr-Mo alloys, titanium alloys and more specialized alloys such as Au- $\mathrm{Pd}^{4}$.

In addition to its unique physical, chemical and mechanical properties, titanium exhibits characteristics related specifically to biomechanics, including resistance to corrosion and reactivity, due to the rapid formation of an oxide layer on the surface when in contact with organic tissues; density appropriate for use as prostheses is $4.45 \mathrm{~g} / \mathrm{cm}^{3}$ - while that of human bone is $1.35 \mathrm{~g} / \mathrm{cm}^{3}$; modulus of elasticity superior to that of human bone $\left(\mathrm{E}_{\mathrm{Ti}}=116 \mathrm{GPa} ; \mathrm{E}_{\mathrm{bone}}=13.5 \sim 22.5 \mathrm{GPa}\right)$; biocompatibility, because its presence in the organism does not cause rejection (swelling and inflammation) at the implant site or in the biological system (allergies); biofunctionality, performing esthetic and practical functions (static and dynamic), due to its dimensional stability; bioinert characteristic since there is

*e-mail: gustavo.lucca@satc.edu.br practically no fibrous encapsulation around the prosthesis; in addition to being sterilizable ${ }^{4-8}$.

The titanium surface has been extensively studied due to the formation of oxides in contact with the fluids. Two classes of surface modification are described in the literature: textures (including patterns and pores) and chemical modifications. On a millimeter scale, several studies seek to understand the natural roughness of titanium and its influence on performance. A wide range of roughnesses and textures have made it possible to understand the relation of this characteristic with bone contact. However, textures/pores in a range of $100 \mu \mathrm{m}$ and $500 \mu \mathrm{m}$ are likely important ${ }^{9}$.

Certain characteristics are needed with respect to the relationship between the biomaterial and tissue, such as the physicochemical interface phenomena related to the first contact between the biomaterial, tissue and implantation environment; tissue and organic medium response to the presence of the material; changes in the materials as a result of the action of the medium (tissue, organic fluids): degradation and corrosion; and reaction of some part of the organism, not directly in contact with the implant ${ }^{10,11}$.

Among the manufacturing processes, incremental sheet forming uses low-cost generic tools to produce sheets with different geometric shapes ${ }^{6}$. The process demonstrates a number of applications in terms of the need to manufacture complex three-dimensional parts without using specific tools when compared to conventional forming ${ }^{6,8}$. In addition, the ISF process to manufacture prototypes or small batches of 
parts is not feasible with conventional ISF because of the high costs involved ${ }^{12}$.

Different studies ${ }^{10,13}$ on ISF processes have shown that forming capacity increases with a decline in tool and vertical step size $(\Delta Z)$, and decreases with sheet thickness; high vertical step sizes raise roughness; a rise in vertical step size and tool diameter increases deformation forces; since there is a maximum wall angle limitation in a single pass, several passes are needed for forming with large wall angles; the spiral tool path is preferable to its contour counterpart; lubrication is essential for the tool to be able to slide and distribute the touch pressure on the sheet, preserving the integrity of both ${ }^{14,15}$.

The problems caused by elastic return are greater in ISF than in traditional processes. Although it is easy to implement and low-cost, its characteristic deformation mechanism is quite complex, and the resulting elastic return significantly compromises final precision. Moreover, the process parameters often exert conflicting influences on different aspects of the final result, including material formability, geometric precision, surface roughness and process time. All of these characteristics make compensating elastic return in ISF a difficult challenge ${ }^{16,17}$.

Deformation in different areas of a stamped component varies from one point to another. Thus, the aim is to use methods and procedures to decrease elastic return of the sheet after forming, in order to reach the closest possible ideal value to the expected geometry, thereby avoiding substantial discrepancies in the stamped part at the end of the process ${ }^{18}$.

Titanium and its alloys are heat treated to develop specific microstructures and mechanical, properties for particular applications. Heat treatments can also be combined with sequential thermo-mechanical processes to further improve the properties and optimize the microstructures of a desired device or component ${ }^{19}$.

The stress relieving process is a low-temperature treatment, typically between $483^{\circ} \mathrm{C}$ and $704^{\circ} \mathrm{C}$, followed by controlled cooling. High temperatures normally relieve stresses in a short time, occurring with greater intensity in the first minutes and stabilizing after 15 minutes. Slow cooling in an oven is necessary to avoid the emergence of new internal stresses. This process relieves internal stresses that occur during manufacturing, such as forging, welding, machining, etc ${ }^{14}$.
Wettability is a physical characteristic of biocompatible materials surface that increases bone apposition and promotes cell adhesion, growth and proliferation on the implant surface, making it more stable and adhered to organic tissues. It is a technique that involves measuring the angle formed at the liquid-air-surface interface; in particular the angle formed between a plane tangent to a drop of liquid and a plane containing the surface where the liquid is deposited ${ }^{2,20}$

The present study aimed at investigating the behavior of the wettability angle as well as the geometric discrepancy of a cranial prosthesis produced by incremental sheet forming. The study was conducted using geometric analysis with 3D scanning and an apparatus built in the laboratory to measure the wettability angle.

\section{Material and Methods}

\subsection{Material}

The material used in the study was pure titanium grade 2 - ASTM F67, supplied by the Realum company and analyzed in the laboratory using a Shimadzu EDX 7000 X-ray fluorescence spectrometer, available at the Center for Technology of University Center UNISATC. The sheet obtained from the company contains $98.71 \%$ titanium.

\subsection{Methods}

First, incremental titanium sheet forming was performed using a special tool made of 4340 steel (non-biomedical) and the pure titanium grade 2 insert (tip). A CNC Romi D 600 device with an advancing speed along the XY axes of $800 \mathrm{~mm} / \mathrm{min}$, drilling speed along the $Z$ axis of $300 \mathrm{~mm} / \mathrm{min}$, free rotation with parallel tool movement, containing a $\mathrm{Z}$ increase of $0.3 \mathrm{~mm}$. An alternative inert characteristic of animal origin (pig fat) was used. After incremental sheet forming, the prosthesis was removed to undergo heat treatment, in order to relieve stresses and reduce elastic return.

Heat treatment was performed at three temperatures, according to the literature $\left(480^{\circ} \mathrm{C}, 540^{\circ} \mathrm{C}\right.$ and $595^{\circ} \mathrm{C}$ (Figure 1). The furnace used was of the muffle type, in an uncontrolled atmosphere. A heating ramp of $20^{\circ} \mathrm{C}$ per minute was used
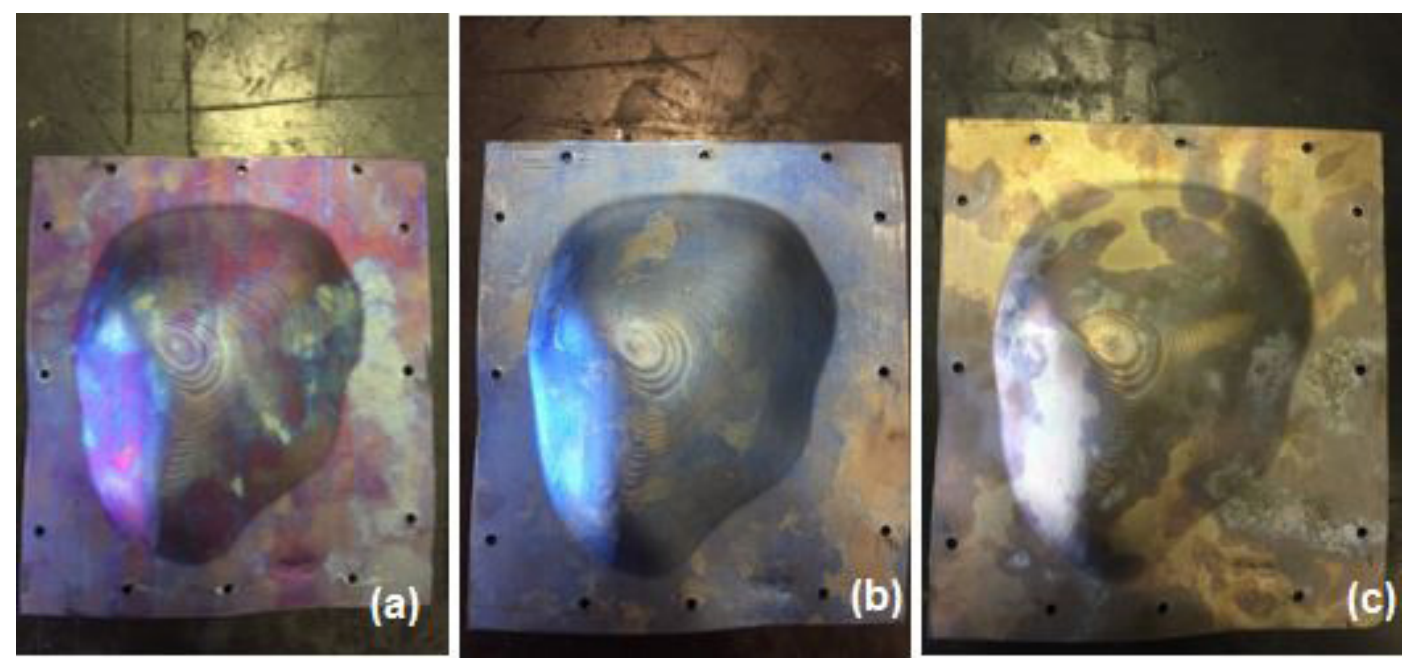

Figure 1. Heat-treated samples: (a) Temperature of $480^{\circ} \mathrm{C}$. (b) $540{ }^{\circ} \mathrm{C}$. (c) $595^{\circ} \mathrm{C}$. 
until the oven reached the established temperature, which was maintained for 2 hours, after which the oven was turned off and cooled for around 22 hours, totaling approximately 24 hours of heat treatment for each part (Figure 2). After the heat treatment stage, the sheets were cut, and fixed in the mold with screws.

Following heat treatment, cutting and removal from the mold, 3D scanning was used to determine the geometric discrepancy between the CAD model and the final prosthesis. Scanning was carried out in the LdSM (Material Design and Selection Laboratory) of the Federal University of Rio Grande do Sul (UFRGS), using a Tecnodrill DIGIMILL 3D milling and digitization laser scanner, with a tolerance of $\pm 0.2 \mathrm{~mm}$ (Figure 3).

Sample roughness was measured using a Mitutoyo SJ310 surface roughness meter, measuring the external and internal part of the prosthesis.

The wettability angle was determined with a measuring apparatus assembled in the 3D Pronto Laboratory of the University Center UNISATC (Figure 4), using a $1 \mathrm{ml}$ syringe with a $4.5 \times 13 \mathrm{~mm}$ needle and a Mitutoyo depth micrometer of 0 to $75 \mathrm{~mm}$, with $0.01 \mathrm{~mm}$ resolution. For the wettability test, the KOKUBO solution produced by the Laboratory for Research in Corrosion (LAPEC) of UFRGS was used. A digital microscope with the manufacturer's software was used to determine the contact angle.

According to guideline D7334-08 ${ }^{21}$, the syringe was placed $3 \mathrm{~mm}$ from the substrate, the $20 \mu \mathrm{L}$ drop limit was controlled by a micrometer, three drops were deposited on the samples, and the contact angles of both sides of the drop were measured, calculating the average of the three drops.

The images were removed 20s after the drop was deposited. The samples were washed with water and neutral soap to remove organic contaminants using the KOKUBO solution.

\section{Results and Discussion}

Figure 5 shows a geometric comparison of the prosthesis as received after removal from the mold (a), and heat treated (b). A significant difference can be seen with the heat treatment process to relieve stresses.

Observing the samples presented in Figure 5, in (b) it is possible to observe a significant amount of oxygen, this is mainly attributed to the use of the oven without a controlled atmosphere. In this way, EDS Mapping was carried out, in order to obtain the amount of titanium before and after heat treatment, as shown in Figure 6. Table 1 is also presented, containing quantitative data.

The results obtained by heat treatment are presented in Figure 7. Figure 7a shows the result of geometric discrepancy analysis for the sample heat treated at $540{ }^{\circ} \mathrm{C}$, Figure $7 \mathrm{~b}$ the result of geometric discrepancy analysis for the sample heat-treated at $540^{\circ} \mathrm{C}$, and Figure $7 \mathrm{c}$ geometric discrepancy analysis of the sample heat treated at $595^{\circ} \mathrm{C}$. The scale shows that the sample (a) displays deviation differences of up to $2.0 \mathrm{~mm}$ between the 3D model and the stamped prosthesis. Quantitative analysis of the samples treated at $540{ }^{\circ} \mathrm{C}$ and $595^{\circ} \mathrm{C}$ obtained a virtual tie. That is, the dimensional deviations were very similar. Qualitative analysis of the two samples demonstrated that the sample at $595{ }^{\circ} \mathrm{C}$ obtained a better result. All the samples exhibit deformations at the points of attachment to the mold. This process had to be performed in order to cut the prosthesis.

The average roughness $(\mathrm{Ra})$ obtained in the prosthesis after ISF was $820 \mu \mathrm{m}$ for the external part and $1100 \mu \mathrm{m}$ for the internal part. The literature ${ }^{13}$ recommends between 100 and $500 \mu \mathrm{m}$ for biomedical materials. As such, polishing was performed using 600 and 1200 grit water sandpaper, obtaining an average of $207 \mu \mathrm{m}$ in the final sample. Figure 8 shows the roughness measurement for the sample treated at $595^{\circ} \mathrm{C}$. The process was conducted

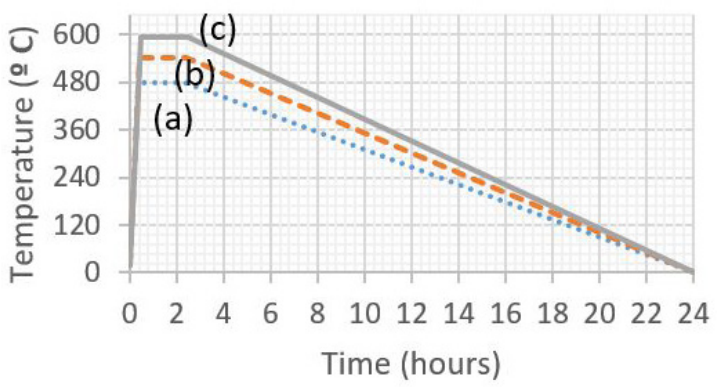

Figure 2. Heating and cooling ramp. (a) Heat treatment at $480{ }^{\circ} \mathrm{C}$; (b) Heated treatment at $540{ }^{\circ} \mathrm{C}$; (c) Heat treatment at $595^{\circ} \mathrm{C}$.

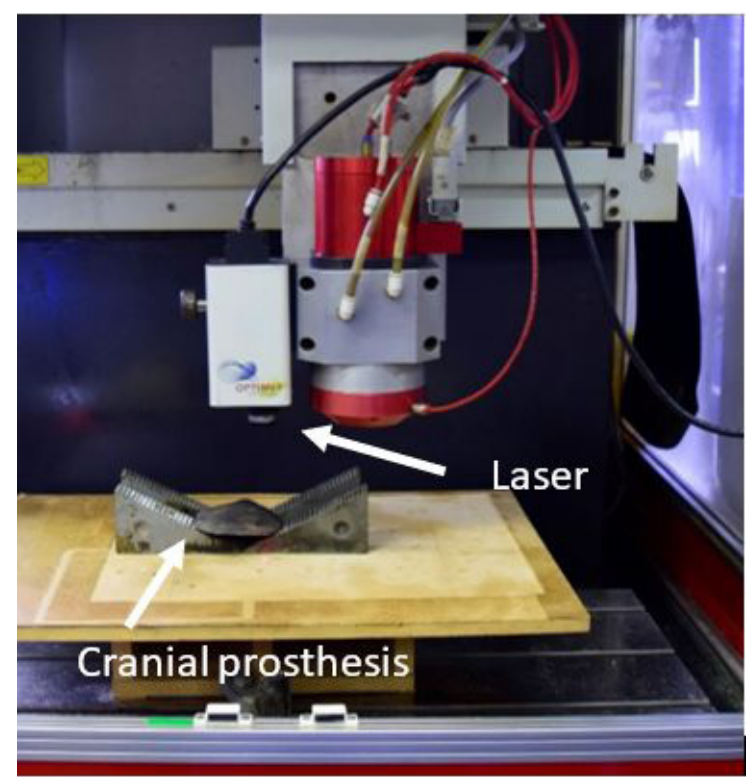

Figure 3. Geometric discrepancy analysis based on the laser incidence (LdSM).

Table 1. Composition of O obtained from the EDS Mapping for the surface of samples before and after UVC irradiation.

\begin{tabular}{lc}
\hline \multicolumn{1}{c}{ Sample } & O (wt., \%) \\
\hline As Received & 11.44 \\
\hline Heat Treated 595 Photofuncionalized (20 min) & 32.12 \\
\hline
\end{tabular}




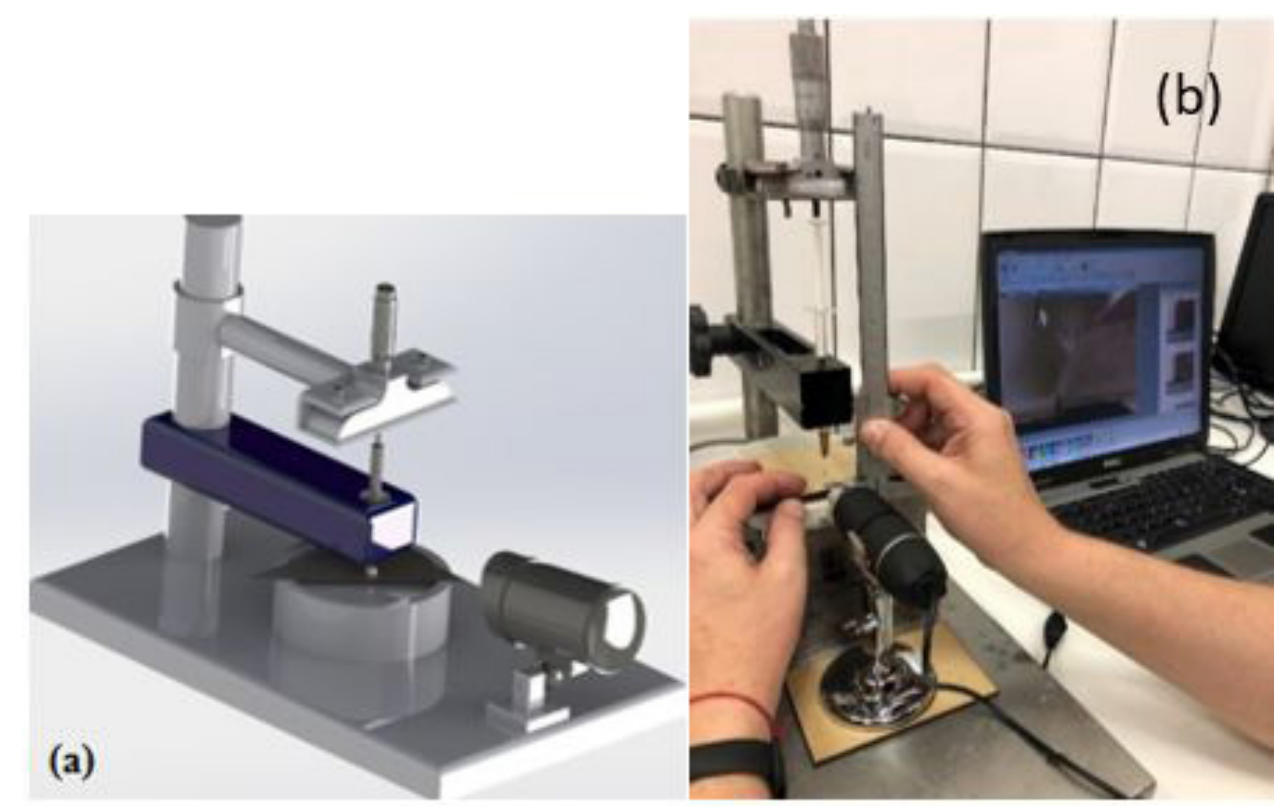

Figure 4. (a) 3D project of the measuring apparatus (b) Measuring apparatus in the Pronto Laboratory 3D.

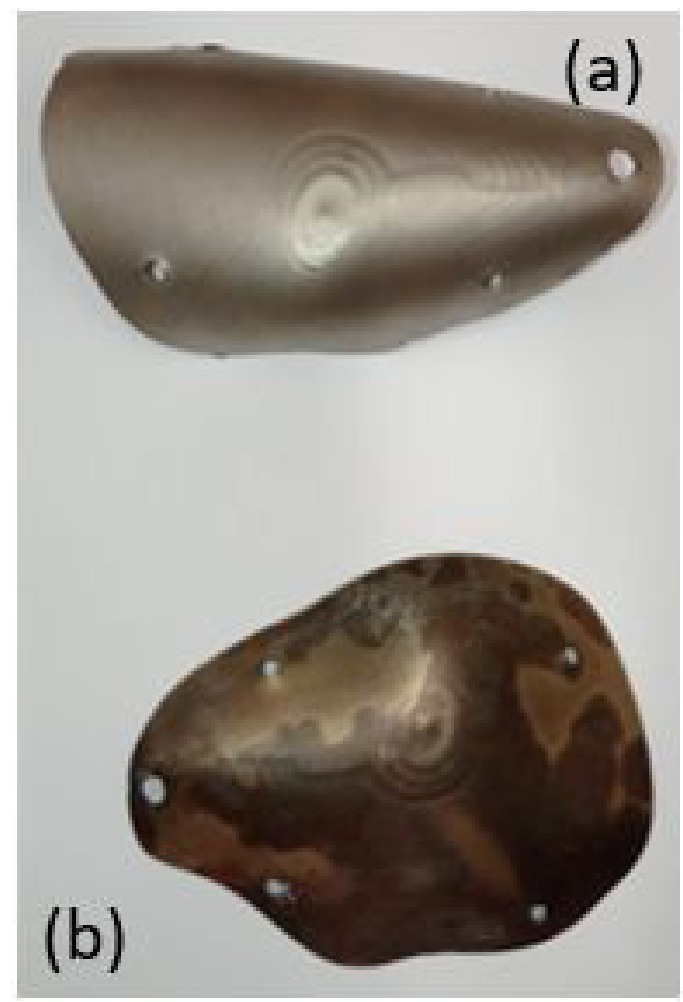

Figure 5. Comparison between samples as received and heat treated at $595^{\circ} \mathrm{C}$.

satisfactorily in order to achieve the objective recommended by the literature.

Figure 9 presents the wettability angle observed in the "as received" sample as substrate. Figure 9a illustrates Drop 1 with the angle measured on both sides, Figure 9b presents Drop 2 with the measures of both sides, and Figure 9c Drop 3 and the angles of both sides. The angle obtained for sample 1 was $94.46^{\circ}$, exhibiting a hydrophobic characteristic on the surface.
Figure 10 presents the results obtained for the sample heat treated at $595^{\circ} \mathrm{C}$. This sample was analyzed because it obtained the best result in geometric discrepancy analysis. Figure 10a shows the angular measures of Drop 1, (b) Drop 2 and (c) Drop 3.

The angle obtained in the sample was $88.80^{\circ}$, characterizing it as hydrophobic, since the angle must be below $45^{\circ}$ to be considered hydrophilic. 
(a)

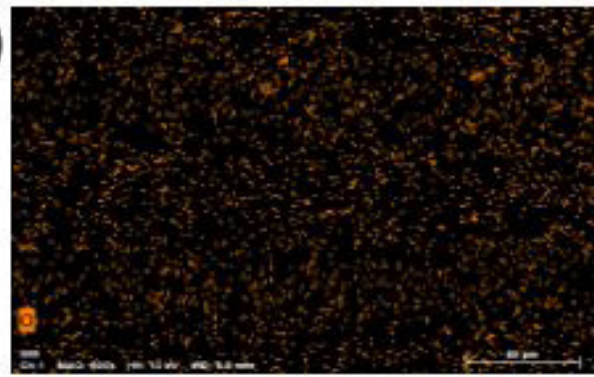

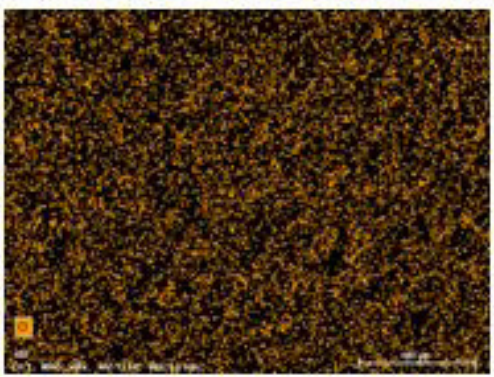

(b)

Figure 6. Analysis by EDS Mapping: (a) amount of $\mathrm{O}$ in the "as received" sample; (b) amount of $\mathrm{O}$ in the sample heat treated at $595^{\circ} \mathrm{C}$.
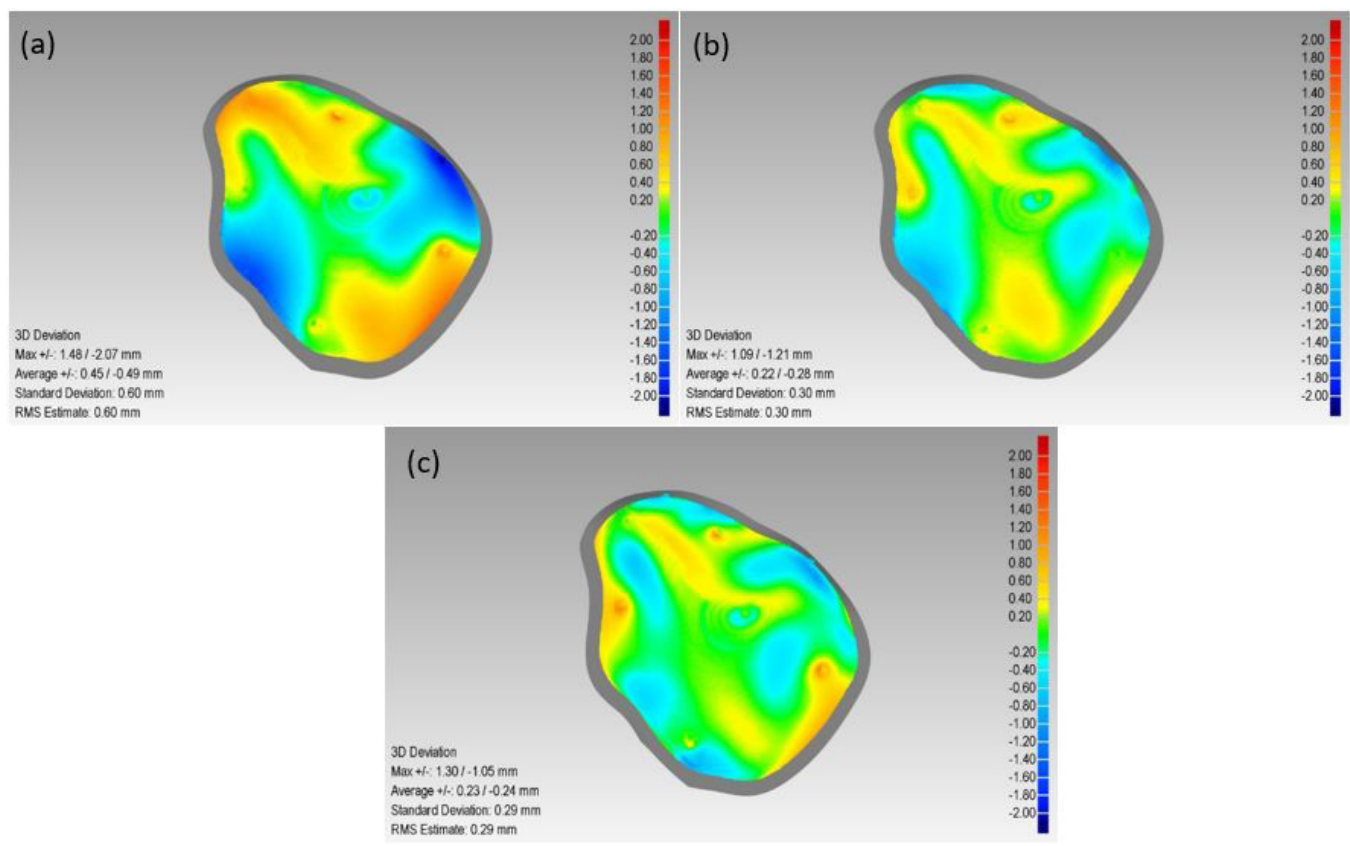

Figure 7. (a) $\mathrm{TT}$ of $480{ }^{\circ} \mathrm{C}$; (b) $\mathrm{TT}$ of $540{ }^{\circ} \mathrm{C}$; (c) $\mathrm{TT}$ of $595^{\circ} \mathrm{C}$.

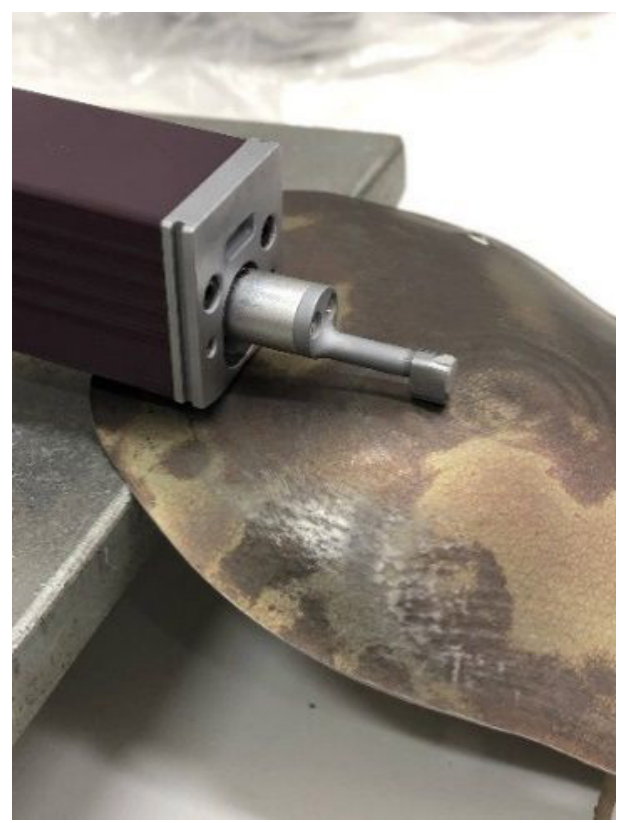

Figure 8. Roughness in the central region of the sample treated at $595^{\circ} \mathrm{C}$. 

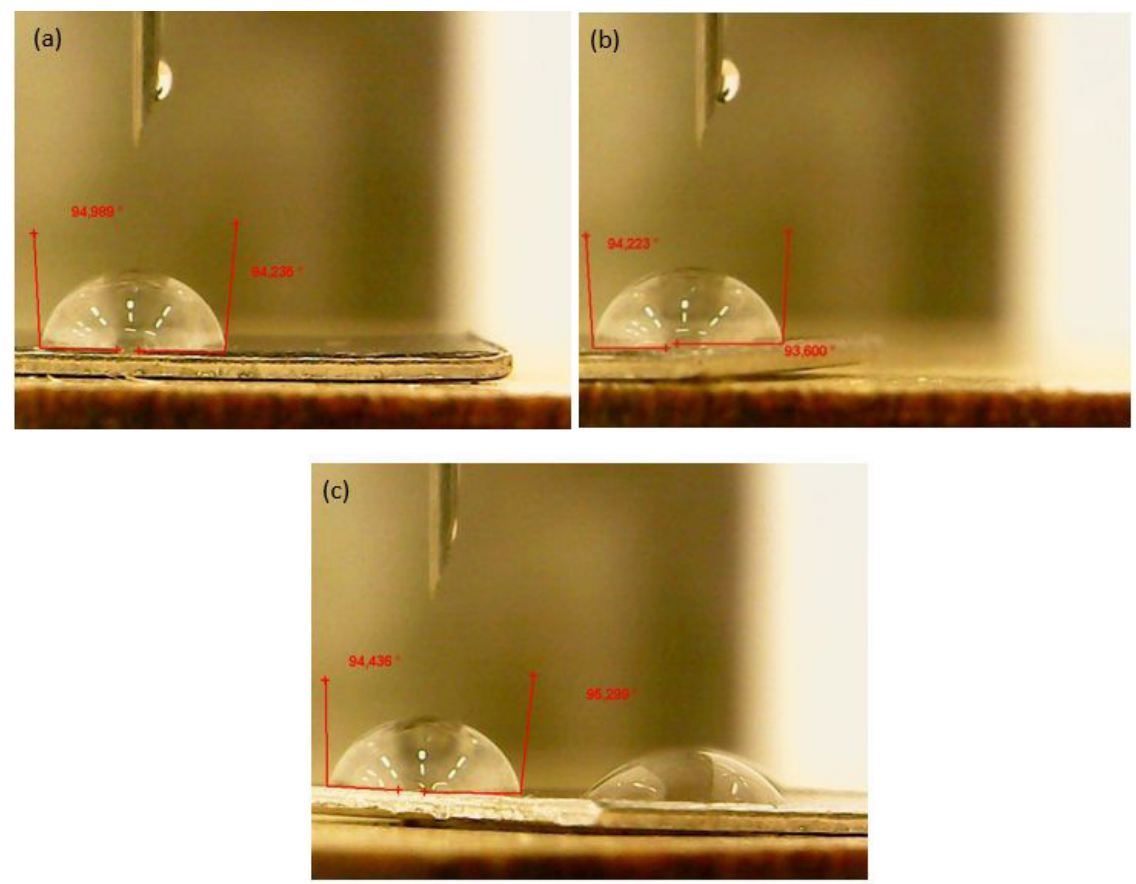

Figure 9. Wettability of the "as received" sample. (a) Drop 1, (b) Drop 2 and (c) Drop 3.
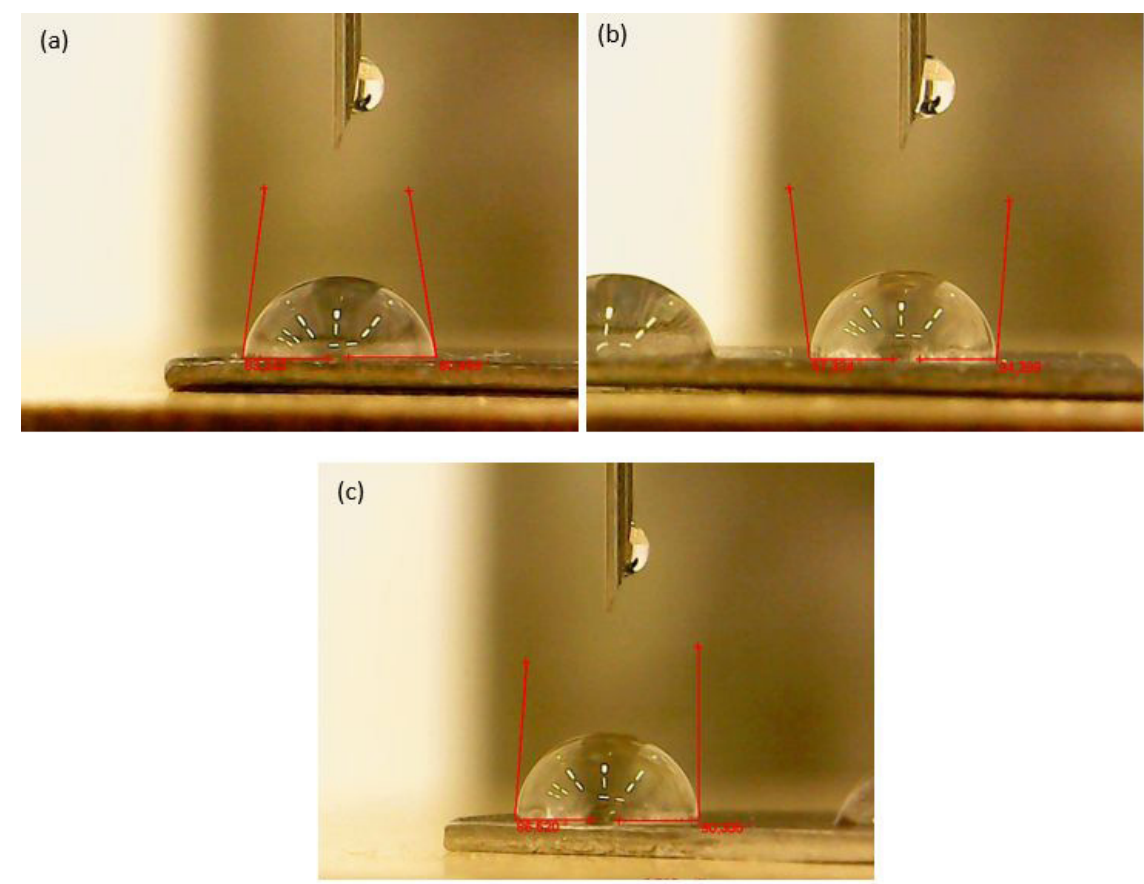

Figure 10. Wettability angle of the sample heat treated at $595^{\circ} \mathrm{C}$; (a) Drop 1, (b) Drop 2 and (c) Drop 3.

\section{Conclusion}

Heat treatment of $595^{\circ} \mathrm{C}$ obtained the best result using $3 \mathrm{D}$ scanning of the prosthesis. The roughness recommended by the literature was also achieved. Comparison with the result obtained for the contact angle demonstrates an average decline of only $5^{\circ}$. Thus, other surface treatment processes are needed to transform the sample from hydrophobic to hydrophilic. However, the heat treatment performed achieved the initial goal, which is to provide the patient with comfort and good esthetics. The change in sample roughness exhibited a better result than roughness outside literature standards.

\section{Acknowledgment}

The authors thank LdTM, LAPEC, LsDM da UFRGS and the 3D Pronto Laboratory of the UniSATC University Center for their help in conducting this study. 


\section{References}

1. Daleffe A. Fabricação de próteses cranianas personalizadas em chapas de titânio através da estampagem incremental fabricação de próteses cranianas personalizadas em chapas de titânio através da estampagem incremental [tese]. Porto Alegre: UFRGS; 2014.

2. Boonrawd W, Awad KR, Varanasi V, Meletis EI. Wettability and in-vitro study of titanium surface profiling prepared by electrolytic plasma processing. Surf Coat Tech. 2021;414:127119. http://dx.doi.org/10.1016/j.surfcoat.2021.127119.

3. Pantaroto HN, Almeida AB, Gomes OP, Matos AO, Landers R, Casarin RCV, et al. Outlining cell interaction and inflammatory cytokines on UV-photofunctionalized mixed-phase $\mathrm{TiO}_{2}$ thin film. Mater Sci Eng C. 2021;118:111438. http://dx.doi.org/10.1016/j. msec.2020.111438.

4. Castelan J. Estampagem incremental do titânio comercialmente puro para aplicação em implante craniano [tese]. Porto Alegre: UFRGS; 2010.

5. Sam Froes FH. Titanium for medical and dental applications: an introduction. In: Froes FH, Qian M, editors. Titanium in medical and dental applications. Amsterdam: Elsevier; 2018. p. 3-21. (Woodhead Publishing Series in Biomaterials) [cited 2018 May 31]. Available from: http://linkinghub.elsevier.com/ retrieve/pii/B9780128124567000019

6. Okubo T, Ikeda T, Saruta J, Tsukimura N, Hirota M, Ogawa T. Compromised epithelial cell attachment after polishing titanium surface and its restoration by UV treatment. Materials. 2020;13(18):3946.

7. Arroyo-Lamas N, Ugalde U, Arteagoitia I. Decontamination of Ti oxide surfaces by using ultraviolet light: hg-vapor vs. LED-based irradiation. Antibiotics. 2020;9(11):724. http:// dx.doi.org/10.3390/antibiotics9110724.

8. Pacheco VN, Nolde J, Quevedo AS, Visioli F, Ponzoni D. Improvement in the chemical structure and biological activity of surface titanium after exposure to UVC light. Odontology. 2021;109(1):271-8. http://dx.doi.org/10.1007/s10266-02000540-w.

9. Luke Yeo IS. Modifications of dental implant surfaces at the microand nano-level for enhanced osseointegration. Materials. 2020;13(1):89.
10. Ogawa T. Ultraviolet photofunctionalization of titanium implants. Int J Oral Maxillofac Implants. 2014;29(1):e95-e102. http:// dx.doi.org/10.11607/jomi.te47.

11. Costa DD, Pedrini H, Bazan O. Usinagem de próteses a partir de imagens tomográficas. In: III Congresso Brasileiro de Engenharia de Fabricação (COBEF 2005); 2005; Joinville. Anais. Rio de Janeiro: ABCM; 2005 [cited 2018 May 31]. Available from: http://www.docdatabase.net/more-usinagemde-pr211 teses-a-partir-de-imagens--1043329.html

12. Carvalho GA, Lopes JC, Vicente FB. Estudo da influência do tratamento térmico na microestrutura do Ti (Titânio) grau 2. Rev Cienc Tecnol. 2017;20(36):67-74.

13. Ratner BD. A perspective on titanium biocompatibility. In: Brunette DM, Tengvall P, Textor M, Thomsen P, editors. Titanium in medicine: material science, surface, science, engineering, biologial responses and medical applications. Berlin: Springer; 2001. p. 1-12.

14. Amino. Dieless NC Forming Catalog. Canada; 2012. p. 1-4.

15. Jeswiet J, Micari F, Hirt G, Bramley A, Duflou J, Allwood J. Asymmetric single point incremental forming of sheet metal. CIRP Ann. 2005;54(2):88-114. http://dx.doi.org/10.1016/ S0007-8506(07)60021-3.

16. Paniti I, Somló J. Novel incremental sheet forming system with toolpath calculation approach. Acta Polytech Hung. 2014;11(7):43-60.

17. Malwad DS, Nandedkar VM. Deformation mechanism analysis of single point incremental sheet metal forming. Procedia Mater Sci. 2014;6:1505-10. http://dx.doi.org/10.1016/j.mspro.2014.07.130.

18. Meier H, Magnus C, Smukala V. Impact of superimposed pressure on dieless incremental sheet metal forming with two moving tools. CIRP Ann Manuf Technol. 2011;60(1):327-30.

19. El-Hadad S, Nady M, Khalifa W, Shash A. Influence of heat treatment conditions on the mechanical properties of Ti-6Al-4V alloy. Can Metall Q. 2018;57(2):186-93. http://dx.doi.org/10. 1080/00084433.2017.1412557.

20. Kaseem M, Choe H. Simultaneous improvement of corrosion resistance and bioactivity of a titanium alloy via wet and dry plasma treatments. J Alloys Compd. 2021;851:156840. http:// dx.doi.org/10.1016/j.jallcom.2020.156840.

21. American Society for Testing and Materials - ASTM. ASTM D7334-08: standard practice for surface wettability of coatings, substrates and pigments by advancing contact angle measurement. Annu B ASTM Stand. 2008;8:1-3. 